\title{
A psicologia moral de Sêneca: a relação entre a disposição da alma e a vida feliz
}

\section{Seneca's moral psychology: the relationship between the disposition of the soul and the happy life}

Mariana Monteiro Condé

Universidade Federal de Minas Gerais (UFMG), Belo Horizonte, Minas Gerais, Brasil. marianaconde01@gmail.com

Resumo: o presente estudo tem por objetivo explicitar de que modo a disposição de alma pode distanciar-nos ou aproximar-nos da vida feliz, na filosofia moral de Sêneca. Para tanto, busca-se analisar e discutir principalmente a epístola XIII das Epistulae Morales, na qual o autor oferece uma descrição da vida desgraçada que leva aquele que é acometido pelo temor - fenômeno psicológico que, por constituir uma das principais paixões, poderá incorrer num prejuízo para a capacidade do homem de atribuir valores, seja a si mesmo, seja ao que lhe é externo. Por outro lado, e tendo em vista as considerações tecidas, busca-se argumentar que é principalmente a força de alma do sapiens que parece aproximá-lo do ideal ético estoico da tranquillitas animi.

Palavras-chave: Sêneca; psicologia moral; paixões; vida feliz.

Abstract: the present paper has as its objective to make explicit in which manner the disposition of the soul can set one apart or close to the happy life, in Seneca's moral philosophy. In order to do so, the analysis and discussion is focused on the $13^{\text {th }}$ epistle of the Moral Epistles (Epistulae Morales), in which the author displays a description of the disgraceful 
life, that is lead by the one who is stricken by dread - a psychological phenomenon that, due to its consisting in one of the main passions, may incur into an impairment on man's value attribution skills (whether to himself, whether to what is external to him). On the other hand, and having in mind the written considerations, it is attempted to argue that it is specially the strength of soul of the wise man (sapiens) that seems to place him close to the stoic ideal of the tranquility of the soul (tranquillitas animi).

Keywords: Seneca; moral psychology; passions; happy life.

Recebido em 05 de março de 2015. Aprovado em 18 de maio de 2015.

\section{Introdução}

O processo de investigação a que nos propomos ao buscar elucidar a relação entre a disposição de alma e a vida feliz contempla o imbricamento entre dois campos da atividade de pesquisa filosófica, a saber, a ética e a psicologia, ${ }^{1}$ entendidas, neste sentido, como âmbitos prescritivos e descritivos, respectivamente. De fato, a compreensão do modo como um dado estado de alma - a partir da análise de sua descrição - pode conduzir a ações éticas que configurem o processo de alcance da vida feliz nos parece constituir uma espécie de investigação que relaciona, a um só tempo, os domínios da psicologia e da ética, tal

\footnotetext{
${ }^{1}$ Vale lembrar aqui, inicialmente, que a filosofia, para os estoicos, era constituída de três partes, a saber, a física, a ética e a lógica. E o estudo da noção de psyché ou anima, a qual certamente estava carregada de uma grande variedade de sentidos, estava incluído no domínio da física, já que poderia se referir, por exemplo, às funções vitais dos seres humanos, dos animais ou de Deus, enquanto princípio ativo do mundo. Como a natureza humana individual é parte da natureza universal, física e ética mostram-se irreversivelmente amalgamadas e, para uma vida ética, o estudo da física tornar-se-ia tarefa fundamental. Cf. Diógenes Laércio VII, 132, LS 43B; LS 45; LS 53. Para leitura e citação dos fragmentos dos antigos estoicos neste estudo, valemo-nos das edições de Arnim e Long e Sedley, as quais serão referidas, respectivamente, pelas siglas SVF e LS.
} 
como entendidas pelos antigos. ${ }^{2}$ Neste sentido, investigações desta ordem parecem pertencer a um domínio que tem sido chamado nos estudos recentes sobre o estoicismo de "psicologia moral".

A fim de definir com mais propriedade o problema do qual nos ocuparemos no decorrer do presente estudo - bem como a área de investigação ao qual o mesmo pertence -, lembremos o esclarecimento de Sêneca a propósito da constituição da ética:

Ergo cum tripertita sit philosophia, moralem eius partem primum incipiamus disponere. Quam in tria rursus diuidi placuit, ut prima esset inspectio suum cuique distribuens et aestimans quanto quidque dignum sit, maxime utilis — quid enim est tam necessarium quam pretia rebus inponere? - secunda de impetu, de actionibus tertia. Primum enim est ut quanti quidque sit iudices, secundum ut impetum ad illa capias ordinatum temperatumque, tertium ut inter impetum tuum actionemque conueniat, $u t$ in omnibus istis tibi ipse consentias. (Ep. LXXXIX, 14) ${ }^{3}$

Assim, procuraremos concentrar-nos na tarefa de esclarecer, no decorrer deste estudo, de que modo as tendências (hormaí, impetus) de cada um de nós - as quais são determinadas a partir do modo como atribuímos valores às coisas que nos são externas - podem revelar as constituições de nosso caráter e, consequentemente, nosso posicionamento diante da vida feliz (uita beata). Dito isto, assim procederemos: num

\footnotetext{
${ }^{2}$ Segundo Brennan, no que se refere à concepção antiga da relação entre psicologia e ética, "a psique humana que representa de modo perfeito pertence ao agente humano perfeitamente ético. Violações de padrões éticos refletem sempre lapsos na higiene psicológica". Cf. BRENNAN, apud INWOOD, 2006, p. 287.

3 "Logo, sendo a filosofia tripartida, a primeira parte dela, a moral, comecemos a ordenar. Aprouve que fosse, de novo, dividida em três, de modo que a primeira parte consistisse no exame que atribui a cada coisa o devido e estima o quanto cada qual é valiosa - algo utilíssimo. O que, pois, é tão necessário quanto atribuir valor às coisas? A segunda trata dos impulsos, e a terceira, das ações. De fato, primeiro se dá que julgues o quanto cada coisa vale, em seguida, que tomes em relação a elas um impulso ordenado e moderado; em terceiro lugar, harmonizarem-se o teu impulso e a tua ação, de modo que estejas de acordo contigo mesmo em todas essas condições". As traduções do latim para o português dos trechos das Epistulae citados no corpo do texto são de nossa autoria; exceções, se houver, serão expressamente indicadas.
} 
primeiro momento, trataremos de explicitar a disposição do homem temeroso frente ao estado ideal ético estoico, valendo-nos, para tanto, das descrições apresentadas por nosso autor acerca dos fenômenos psíquicos relativos à paixão do temor. Compreendido o fenômeno do temor como responsável pela determinação da disposição perturbada e desgraçada do temeroso, e detalhados os principais aspectos desta paixão, delinearemos uma imagem - a de um jogo de opostos -: a vida atormentada do temeroso contrastada com a tranquilidade de vida do sábio. Então, considerações serão tecidas sobre a maneira como ambos, sábio e temeroso, reagem, cada um a seu modo, aos fenômenos externos. Por fim, retomaremos nossas reflexões, dando seguimento à nossa argumentação mais geral, a saber, aquela que busca relacionar a disposição de alma com a vida feliz.

\section{A descrição do estado de alma do homem temeroso}

Não obstante constar entre as primeiras das 124 Epistulae, a epístola XIII - para além da correspondência entre a temática ali abordada e o momento de tensão vivido por Sêneca nos últimos anos de sua vida, conforme já destacado por Pierre Grimal -4 nos oferece elementos capazes de suscitar relevantes questões acerca da polêmica relação entre a paixão do temor e a vida feliz: ora, é aí que Sêneca procura defender a ideia de que não se deve fugir nem temer o combate, porque temores e angústias são, muitas vezes, fruto de nossa opinião (opinio) e não da realidade (Ep. XIII, 4).

Embora, numa primeira leitura, a linguagem da qual Sêneca se vale possa nos parecer das mais simples e claras, muitos problemas se nos apresentam já num primeiro momento: que combate está aqui em questão? O que constituem então temores e angústias? De que modo os mesmos podem ser tomados como representações equivocadas?

\footnotetext{
${ }^{4}$ GRIMAL, 1979, p. 232: “C'est dans cette volonté de refuser toute crainte, en même temps que dans l'acceptation de l'inévitable que réside en bonne partie le secret de la sérénité conquise par Sénèque. La lettre 13 est le commentaire de cette attitude, que Sénèque voulait exemplaire pour son ami. Il est bien probable que cette lettre n'est pas éloignée, dans le temps, des accusations portées par Romanus contre le philosophe. S'il en est bien ainsi, telles expressions prennent, sous la plume de Sénèque, une valeur singulièrement précise et émouvante".
} 
Uma análise mais detida da referida epístola pode servir para evidenciar que, num primeiro momento, Sêneca se ocupa em cunhar imagens para introduzir o problema de seu interesse: símiles sobre atletas e guerreiros sugerem que ambos necessitam de força e esforço para terem sucesso em seus combates. Trata-se, ao que parece, de combates travados contra a fortuna. A imagem ainda sugere que apenas o constante exercício da luta pode nos deixar prontos para combatermos bem:

Non potest athleta magnos spiritus ad certamen afferre qui numquam suggillatus est: ille qui sanguinem suum uidit, cuius dentes crepuere sub pugno, ille qui subplantatus ad uersarium toto tulit corpore nec proiecit animum proiectus, qui quotiens cecidit contumacior resurrexit, cum magna spe descendit ad pugnam. (Ep. XIII, 2) ${ }^{5}$

Ditas tais palavras, Sêneca passa então à introdução do problema, em seu âmbito conceitual: mais numerosos são os nossos temores que nossas aflições. O problema em questão, então, se desvela: é éticopsicológico. E o combate ao qual Sêneca faz alusão é, ao que nos parece, interior. A este respeito, há dois passos presentes na referida epístola, e que gostaríamos de analisar em conjunto:

Plura sunt, Lucili, quae nos terrent quam quae premunt, et saepius opinione quam re laboramus. (Ep. XIII, 4) ${ }^{6}$

Quaedam ergo nos magis torquent quam debent; quaedam ante torquent quam debent; quaedam torquent, cum omnino non debeant, Aut augemus dolorem aut praecipimus aut fingimus. (Ep. XIII, 5)

\footnotetext{
5 "Não pode o atleta levar para a disputa um ânimo elevado, se nunca foi batido; aquele que viu seu sangue, cujos dentes se quebraram sob golpes, aquele que, derrubado, suportou com o corpo todo o peso do adversário e, abatido, não deixou abater seu ânimo, mas a cada golpe se reergueu com mais obstinação, com grande esperança se dirigiu à luta".

6 "Mais numerosas são, Lucílio, as (coisas) que nos aterrorizam, do que as que nos abatem; e muitas vezes nos afligimos mais por conta da opinião do que pela realidade". 7 "Certas coisas nos atormentam mais do que devem, outras nos atormentam antes do que devem, e outras nos atormentam, embora sem que de forma alguma o devessem. Ou aumentamos a dor, ou a antecipamos, ou a inventamos".
} 
Para além dos problemas relativos às múltiplas traduções possíveis para a rica linguagem senequiana - os quais não pretendemos tratar a fundo aqui - o que nos salta aos olhos numa primeira leitura é que os passos em questão se dirigem, ambos, ao fenômeno psíquico do temor. Se o primeiro passo se refere ao modo como nós, seres humanos adultos e racionais, interpretamos as causas de nossos temores, o segundo trata das características do estado de alma daqueles que se encontram tomados por estes temores. Uma leitura mais minuciosa poderia nos sugerir que os referidos passos parecem tratar de dois momentos psíquicos contínuos, embora distintos. Se nossa interpretação está correta, e a imagem de combate levantada por Sêneca no início da epístola pretende remeter à ideia de um combate interior, parece-nos, então, que o que está em jogo no primeiro passo é uma luta travada contra nossas tendências interiores de deixarmo-nos afetar de modo particular por coisas e eventos externos - vale salientar, a ênfase aqui recai antes sobre o modo, e não meramente sobre o fato de deixarmo-nos afetar. O segundo passo, ao que nos parece, contempla um segundo momento psicológico: trata-se, então, daquele que, já afetado, tendo o ânimo já dominado pelo temor, revela, em seu modo de agir, os traços da paixão-temor: o exagero, a antecipação, e a criação de novas causas de temores.

O homem temeroso, portanto, parece ser aquele que, além de tomar as coisas e eventos externos de modo exagerado, hipervalorizandoos, revela-se incapaz de situá-los no tempo, trazendo-os, vez ou outra, ao presente, antecipando, sentindo e ressentindo o sofrimento da angústia relativa a possíveis males futuros. Sêneca ainda nos fala de outro aspecto: a criação de causas de temor - causas estas, inexistentes. Como, esperemos, ficará mais claro adiante, a criação de causas de temor por parte da alma parece ser um aspecto convergente àquele que se refere ao exagero, uma vez que é a falta de medida que os caracteriza: os males inventados, por não encontrarem correspondência alguma com a realidade, podem facilmente ser aumentados e exagerados. A recíproca, entretanto, não parece ser verdadeira, já que nem sempre os temores exagerados serão oriundos de nossa imaginação. Por ora, parece-nos suficiente informar que Sêneca se ocupará do detalhamento destes aspectos no decorrer da epístola XIII, buscando argumentar, pela descrição, de que modo a vida do temeroso parece ser das mais infelizes: o homem angustiado e oprimido pelo temor de males futuros vive no mais completo estado de perturbação - nulla autem causa uitae est, nullus miseriarum modus, si 
timetur quantum potest. ${ }^{8}$

\section{0 conceito de temor}

A epístola XIII encontra-se carregada de termos relativos à paixão do temor; seja de modo implícito ou explícito na letra do texto. E se por um lado Sêneca não parece tão preocupado em oferecer a definição precisa do que seja o temor, a análise atenta de suas descrições da vida infeliz do temeroso aí presentes pode nos permitir uma tentativa de esboçar limites para o referido conceito.

Já no início da referida epístola, encontramos um passo em que nosso autor relaciona, a um só tempo, coisas que nos angustiam (torquere) - ou, em outras palavras, coisas que nos oprimem - a noções como exagero, antecipação e opinião. A passagem supracitada enfatiza, em seguida, a relação entre o temor e a angústia e a intuição da temporalidade - ênfase esta traduzida pelo conselho de Sêneca: ne sis miser ante tempus. ${ }^{9}$

Outra noção que se faz recorrente na epístola XIII é aquela referente à opinião (opinio), à infâmia (infamis) e à boataria (fama): tais termos encontrar-se-ão relacionados ao temor no sentido de que, muitas vezes, tombamos mais pelo que ouvimos, do que pelo que realmente nos acomete; não analisamos criticamente as causas de nossos temores e deitamos a correr, batendo em retirada, como soldados que fogem por causa da poeira levantada (Ep. XIII, 6-8).

Num outro momento, o temor, em sua perspectiva mais extrema, a do pânico (lymphatici metus), relacionar-se-á à loucura. Incapacitados de analisar as situações cuidadosamente, valendo-nos para tanto de nossa razão, beiramos a irracionalidade e, consequentemente, a loucura ( $E p$. XIII, 9). A epístola sugere ainda que o estado de alma ideal seria, ao contrário, o daquele que é capaz de sopesar as causas de seus temores, de submetê-las à razão e à medida (Ep. XIII, 13). Mesmo porque, do contrário, a vida seria uma desgraça infindável e sem sentido - viveríamos atormentados temendo tudo o que pudesse acontecer. Ora, o sentido da vida encontra-se exatamente no momento presente, o único capaz de nos oferecer possibilidades de agir e de reformar o nosso caráter. E é por isso

${ }^{8}$ SÊNECA, Ep. XIII, 12: "Não há nenhum sentido para a vida e nenhum limite para nossa desgraça, se tememos tudo o que pode acontecer".

${ }^{9}$ SÊNECA, Ep. XIII, 4: "Não sejas infeliz antes do tempo!" 
que a capacidade de intuir a temporalidade é convergente ao ideal ético estoico - é só assim que reivindicamos a nós mesmos.

Aqui, vale lembrar ainda a definição de Sêneca apresentada no passo 11 da epístola LXXXV, na qual o temor consta entre um dos maus impulsos, estando entre aqueles que, uma vez aceites na alma, tenderão à tirania, ganhando corpo e forças de acordo com causas externas:

Deinde, si das aliquid iuris tristitiae, timori, cupiditati, ceteris motibus prauis, non erunt in nostra potestate. Quare? quia extra nos sunt quibus inritantur; itaque crescent prout magnas habuerint minoresue causas quibus concitentur. $(\text { Ep. LXXXV, 11) })^{10}$

Por ora, é possível esboçar, então, três aspectos característicos da paixão do temor, quais sejam, o da antecipação de males - haja vista que o temor atua tornando o homem desesperado antes do tempo -; o do exagero - na medida em que os temerosos revelam-se incapazes de analisar cuidadosamente a verdadeira extensão das causas de males vindouras -; e o da loucura - tendo em vista que, uma vez dominada pela paixão, a alma beira à irracionalidade, em absoluto conflito com sua própria natureza.

Neste sentido, vale dizer: do ponto de vista mais geral de sua definição, o temor, na perspectiva senequiana, enquanto mau impulso, é paixão - e, como tal, caracteriza-se por tomar exageradamente as causas de males, causando perturbações na alma e tornando malsão um estado que deveria estar em conformidade com sua natureza racional; também por isso, se levado a extremo, tenderá à loucura. Em seu aspecto mais específico, o temor nos revela um distúrbio de análise de causas de males futuras - e aquele que se encontra tomado por esta paixão tende a pressentir e ressentir males ainda não ocorridos. ${ }^{11}$

\footnotetext{
10 "Então se tu concedes algum direito à melancolia, ao temor, ao desejo, aos demais maus impulsos, (os mesmos) não estarão sob nosso poder. Por quê? Porque é externo a nós aquilo com que são estimulados, e assim aumentarão mais ou menos, de acordo com as causas que os excitam".

${ }^{11}$ Vale aqui lembrar que, para os antigos estoicos, as paixões constituíam impulsos que se excediam para além da natureza da alma, que é racional (SVF I 205). Crisipo teria sido o responsável por tornar ainda mais complexa esta problemática, oferecendo uma minuciosa classificação dos diferentes tipos de paixões: sendo as quatro principais paixões - o desejo, o temor, a dor e o prazer - marcados por sua relação com a
} 


\section{Aspectos das paixões: o caráter tirânico das paixões; a relação paixão - tempo}

Retomando a definição de temor acima descrita, lembramos que, enquanto paixão, o temor é caracterizado pelos seguintes aspectos, segundo a perspectiva senequiana: o exagero, a antecipação de possíveis males futuros, a criação de novos males. Enquanto traços comuns a todas as paixões, destacamos o exagero e a criação de novos males; por outro lado, é a sua peculiar relação com o aspecto da temporalidade que lhe confere especificidade, diante das demais paixões.

Neste sentido, gostaríamos de tecer algumas considerações acerca do caráter tirânico das paixões para, por fim, discorrer acerca da relação existente entre paixão e temporalidade, tendo como pano de fundo a paixão do temor.

\subsection{O caráter tirânico das paixões}

Do ponto de vista geral de sua definição, o temor - assim como as demais paixões - representa um impulso exagerado ou, em outras palavras, um mau impulso ( $E p$. LXXXV,11). Mas uma questão se coloca: em que medida um impulso, por ser exagerado, se caracteriza como indesejável, do ponto de vista valorativo?

Ora, não é difícil perceber que, dada a natureza da alma humana, a qual tem como elemento dominador o hegemonikón ou, em outras palavras, a razão, toda espécie de ato desmedido representaria um conflito interno, ou ainda, um desarranjo dentro de uma economia global que deveria orientar-se pelas medidas estabelecidas pela razão. ${ }^{12}$

temporalidade, o temor seria o impulso que é marcado pela antecipação de males futuros (SVF III 378, 394). Note-se, a este respeito, que a definição de temor esboçada por Sêneca não está muito distante daquela que formularam os antigos mestres da Stoa. Entretanto - e é o que aqui principalmente argumentamos -, é preciso ter em conta que para o autor romano este conceito terá importância fundamental no sentido de explicitar a relação entre disposição de alma e vida feliz. Ora, assim, como o temeroso é o desgraçado por excelência, o forte e corajoso, ao contrário, muito próximo estará do estado de tranquillitas animi - argumentação esta que, a nosso ver, é muito própria a Sêneca.

${ }^{12}$ Cabe aqui uma ressalva: embora o vocabulário estoico, na lide com o tema das paixões, pareça revelar uma ética orientada pela medida, é bastante importante ter em conta que apenas se atribui às paixões o excesso e o exagero no sentido de que as 
Por outro lado - e ainda seguindo a metáfora da tirania - seria enorme descuido de nossa parte deixar de salientar a força que se traduz em violência, ${ }^{13}$ enquanto atributo das paixões, as quais, então, tendem a dominar a alma. É nessa medida que faz sentido retomar o principal argumento apresentado por Sêneca contra os peripatéticos, o qual se estende pelo De Ira e também pode ser encontrado, por exemplo, na epístola LXXXV: uma vez aceites, as paixões tenderão a dominar a alma, dificilmente podendo ser moderadas. Assim, mais fácil seria evitá-las que moderá-las. ${ }^{14}$ A razão - instância que marca o equilíbrio e a conformação do homem com o universo - muito provavelmente não será recobrada, dado o caráter violento e tirânico dos impulsos excessivos ditos paixões.

Enquanto fenômeno oriundo da má interpretação dos eventos externos da parte do homem - embora sua incidência seja de ordem interna - as paixões acarretarão novas más interpretações e, consequentemente, um estado ímpar de perturbação da alma. E, vale lembrar ainda que, como Sêneca bem nos adverte, uma vez tornados hábito, os impulsos exagerados configurarão vício.

\subsection{As paixões e o tempo}

Lembramos que, do ponto de vista específico de sua definição, a paixão do temor representa a antecipação de um mal futuro - e, aqui, é da questão relativa à temporalidade que gostaríamos de tratar. Antes de tudo, vale dizer que a problemática do tempo exerce, na ética senequiana, função de enorme relevância, e isso se traduz já na primeira das Epistulae, bem como em uma de suas obras mais popularescas, o $D e$

mesmas representam impulsos que excedem os limites estabelecidos pela razão, traço mais importante de nossa natureza e que nos define enquanto homens. Não parece haver, em todo caso, uma concessão à metriopátheia, haja vista que as paixões, por sua própria natureza, não são passíveis de moderação.

${ }^{13}$ Lembramos aqui, a título de ilustração da força oriunda das paixões, a figura da Medeia senequiana: Nulla uis flammae tumidiue uenti/ tanta, nec teli metuenda torti,/ quanta cum coniunx uiduata taedis/ ardet et odit. - "Nem a violência da chama nem a do vento intumescido nem a do dardo lançado ameaçadoramente é tão grande como quando uma esposa desapossada dos fachos nupciais se inflama e manifesta ódio". (Medeia de Sêneca, v. 579-582 - trad. Ana Alexandra Alves de Sousa)

${ }^{14}$ Veja-se a este respeito, por exemplo, o trecho que compreende os passos de 8 a 11, da epístola LXXXV. 
Breuitate Vitae. Ao que nos parece, trata-se, como sói acontecer tantas vezes na obra senequiana, não de definir o que seja o tempo; trata-se, antes disso, de problematizar a intuição da temporalidade na vida humana. Importa saber como o homem intui o tempo, instância mediadora entre nossa vida interior e exterior. Vale ainda indicar, então, o melhor modo de intuí-lo porque, em certa medida, lidar bem com a temporalidade implica em levar uma vida tranquila, o que converge com a principal máxima estoica, aquela que se refere ao estado de imperturbabilidade. Situar corretamente eventos externos no tempo implica, ainda, em aceitálos e, em certa medida, em harmonizar eventos interiores e exteriores. Aprender a lidar com o tempo, com a ideia processual que envolve vida e morte, coincide, em certa medida, com a reivindicação de si mesmo trata-se, em outras palavras, da construção do eu e da fortaleza interior, imagem tão difundida entre os estoicos e não menos vívida nas obras de nosso autor. ${ }^{15}$

Parece-nos que há, para tratar da questão da experiência do tempo vivida pelo homem, ao menos duas perspectivas distintas em Sêneca. Uma delas diz respeito à praemeditatio malorum, uma prática de antecipação dos males, a qual é exercitada no intuito de que o homem se prepare, sempre, antes de enfrentá-los. ${ }^{16}$ A nosso ver, de um modo geral, estão aí em jogo práticas espirituais de preparação - espécies de exercícios ascéticos muito caros ao estoicismo, conforme tão bem explicitado por Hadot. ${ }^{17}$ E parece-nos que, nesse sentido, a praemeditatio malorum - dirigida ao futuro - reflete a valorização da antecipação dos males como forma de exercício interior. Assim, voltar-se para o passado também poderia render bons frutos, embora valha aqui salientar que apenas o sábio tem a capacidade de retomar o passado com segurança e maturidade, a fim de refletir sobre o que se passou - Gretchen ReydamsSchils inclusive salienta este aspecto na filosofia de Sêneca, a saber, o da valorização da reflexão acerca do passado e do futuro. ${ }^{18}$

\footnotetext{
${ }^{15}$ Um exemplo de utilização da imagem da "muralha" interior pode ser encontrado em SÊNECA, Ep. XLIX, 7-10.

${ }^{16}$ Lembramos, a este respeito, a meditação sobre a morte, tema tão recorrente em Sêneca (Ep. LXX, 18).

${ }^{17}$ Com relação às considerações tecidas por Pierre Hadot a propósito dos exercícios espirituais estoicos, cf. HADOT, 1999, p. 201.

${ }^{18}$ REYDAMS-SCHILS, 2005, p. 29-34.
} 
Entretanto, estamos bastante convencidos de que há também, no estoicismo senequiano, outra perspectiva muito importante a respeito da experiência do tempo, a saber, a da valorização do momento presente. Trata-se, neste caso, de evitar o pressentimento de males futuros, uma vez que a antecipação do sofrimento - no caso da paixão do temor reflete uma pré-ocupação do momento presente, o único que possibilita a iniciativa moral, com possíveis adversidades vindouras. Exemplos desta perspectiva podem ser encontrados, sobretudo, na epístola XIII. Embora não tratem especificamente de Sêneca, as abordagens de Goldschmidt ${ }^{19}$ e de $\operatorname{Hadot}^{20}$ oferecem interessantes perspectivas acerca da importância do tempo presente no estoicismo - e, ainda que se mostrem divergentes em relação a aspectos importantes da argumentação estoica, parecem, ambas, dar-nos margem a uma interpretação que valorize o presente, conforme mencionado acima.

A intérprete Mireille Armisen-Marchetti ${ }^{21}$ procura resolver a aparente contradição entre estas duas perspectivas argumentando que o que Sêneca faz, na realidade, ao aconselhar a não antecipação dos males, nada mais é do que pôr em prática uma estratégia para lidar com

${ }^{19}$ Goldschmidt esclarece que "Le propre de la passion est de nous asservir au temps irréel où le passé se survit pour communiquer son existence et son contenu au futur, et où il détruit le seul temps réel, le présent, c'est-à-dire le temps du salut, le seul où puisse se placer l'initiative morale". (GOLDSCHMIDT, 1953, p. 193)

${ }^{20}$ Ao interpretar Marco Aurélio, Hadot tece interessantes considerações sobre a importância de se circunscrever o momento presente - ora, ao tentarmos compreender sua verdadeira natureza, vemos que os instantes são unidades inteiras, fracionadas. Esta perspectiva, do ponto de vista moral, poderia trazer-nos vários benefícios, uma vez que as dificuldades tornar-se-iam mais suportáveis (não precisamos nos desencorajar com representações globais de sofrimento por toda uma vida, haja vista que tratar-seia apenas de instantes); e, ademais, intensificaríamos nossa atenção com relação aos eventos que podem nos acometer - já que a vida urge e a hora da mudança é o agora. Apenas o presente está em nosso poder: "Notre vie réelle se limite à cette pointe minuscule qui nous met en contact, à chaque instant, activement ou passivement, par l'intermédiaire de l'événement présent ou de l'action présente, avec le mouvement général de l'univers". (HADOT, 1992, p. 149) A divergência entre Hadot e Goldschmidt parece ser a de que, para este último o presente não teria realidade, ou apenas teria sua realidade conferida pelo agente moral. Parece ser esta a crítica formulada por Hadot frente à interpretação de Goldschmidt. De resto, as duas leituras são imprescindíveis para a formulação do problema em questão. (HADOT, 1992, p. 148-154)

${ }^{21}$ ARMISEN-MARCHETTI, apud FITCH, 2008, p. 102-113. 
o proficiens em linguagem menos dura que a estoica. Isto, porque apenas o sapiens estaria apto a praticar a praemeditatio malorum.

A hipótese supracitada nos parece, em todo caso, legítima. Entretanto, acreditamos que, mais uma vez e sobretudo no tocante a esta problemática, vale a tentativa de pensar a doutrina estoica como sistema, no intuito de articular a um só tempo física, ética e lógica. ${ }^{22}$ Nesse sentido, pensamos que uma outra interpretação mostrar-se-ia possível se levássemos em conta a influência do conceito de tempo cíclico na ética estoica $-{ }^{23}$ hipótese esta complexa e que demandaria uma maior explicitação de detalhes. Fato é que outros trechos da obra senequiana $^{24}$ nos forneceriam elementos para discutir a valorização do momento presente em sua ética. Nesse sentido, a praemeditatio, enquanto técnica imaginativa, não constituiria projeção no tempo ou pressentimento de males vindouros, mas estratégia racional de preparação e fortalecimento - a qual poderia consistir, ainda, em atribuir valores

${ }^{22}$ Vale aqui, sem dúvida, citar mais uma vez Hadot: "O estoico tem consciência de estar a cada instante em contato com o universo inteiro. É que, em cada acontecimento presente, o universo inteiro está implicado (...) assim, a concentração do eu no presente e a dilatação do eu no cosmos realizam-se em um único instante". (HADOT, 1992, p. 300-301)

${ }^{23}$ A este respeito, retomamos, aqui, as esclarecedoras palavras de Marco Aurélio:

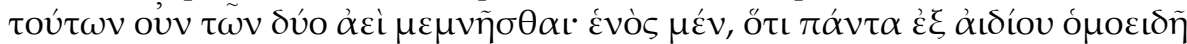

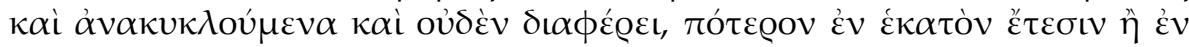

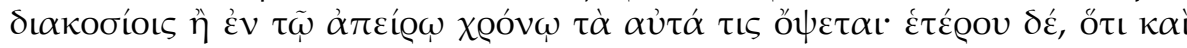

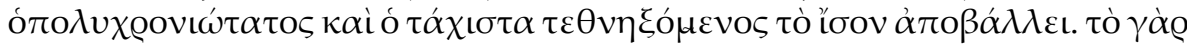

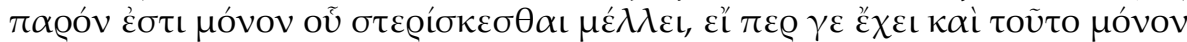

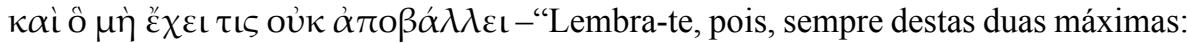
primeira, que tudo, desde todo o sempre, tem o mesmo aspecto e se renova em ciclos; nenhuma diferença faz verem-se os mesmos fatos por cem anos ou por duzentos, ou eternamente; segunda, que a perda é igual tanto para o de vida mais longa como para quem morre cedo, porquanto o presente é a única coisa de que será desapossado, pois só tem este e não perde o que não tem". (MARCO AURÉLIO, Meditações II, 14 trad. Jaime Bruna) Breve menção de Sêneca acerca da circularidade do tempo pode ser encontrada em Ep. XXXVI, 11.

${ }^{24}$ Lembramos, a título de exemplo, o trecho 7-9 da epístola V, no qual Sêneca valoriza a concentração psíquica no momento presente, alertando sobre os perigos da memória se vinculada à hesitação e à preocupação com expectativas futuras. Entretanto, outros trechos poderiam ser retomados, segundo este aspecto (cf., por exemplo, SÊNECA, Ep. I, 2). 
corretos aos fenômenos futuros, valores segundo a razão, e não segundo as paixões. Por outro lado, a apreensão do presente e a reivindicação de si, são atos que possibilitam toda e qualquer reforma moral, inclusive aquelas, de âmbito preparatório. Dito isto, lembramos que o sábio é aquele que vive, psicologicamente, atento ao presente, extremamente concentrado em si mesmo e orientado para aproveitar ao máximo cada minuto de vida - porque sabe que a morte pode chegar a qualquer hora, e que o tempo de caminhar em direção à virtude é o agora (lembremos, aqui, do De Breuitate Vitae).

\section{Considerações sobre a teoria estoica da ação}

Antes de prosseguir com nossa estratégia de explicitar a figura do sábio a partir do delineamento do perfil do temeroso e da delimitação do conceito de temor, fazem-se necessárias algumas considerações. Pensamos que a problematização da questão das paixões ou de estados psíquicos que contemplem a mobilização da alma à ação deve levar em conta, ainda que sumariamente, alguns aspectos da teoria estoica da ação. Pensando o fenômeno da ação humana enquanto processo, retomamos os momentos psíquicos propostos por Sêneca como constituintes da ação: impressão (phantasia/uisum) - impulso (hormé/impetus) - assentimento (synkatáthesis/assensus, aprobatio), os quais são brevemente descritos por nosso autor na epístola CXIII, 18: Omne rationale animal nihil agit nisi primum specie alicuius rei inritatum est, deinde impetum cepit, deinde adsensio confirmauit hunc impetum. ${ }^{25}$

Conforme argumentação desenvolvida nos primeiros passos do livro segundo do De $\mathrm{Ira}^{26}{ }^{26}$ a impressão inicial é involuntária, podendo acometer qualquer um dos tipos humanos - seja o stultus, o proficiens ou o sapiens. Outra menção a esta mesma ideia pode ser encontrada na epístola LVII, 4:

Quaedam enim, mi Lucili, nulla effugere uirtus potest; admonet illam natura mortalitatis suae. Itaque et uultum adducet ad tristia et inhorrescet ad subita et caligabit, si

${ }^{25}$ SÊNECA, Ep. CXIII, 18: "Nenhum animal racional age a não ser que antes tenha sido incitado pela visão de alguma coisa; depois, tomado impulso, depois, confirmado o assentimento tal impulso".

${ }^{26}$ SÊNECA, Ir. II, 3-4. 
uastam altitudinem in crepidine eius constitutus despexerit: non est hoc timor, sed naturalis affectio inexpugnabilis rationi.(Ep.LVII, 4) ${ }^{27}$

Assim, fica claro que o que diferencia substancialmente o sapiens do stultus é o modo como este interpreta o mundo que o circunda - ainda que acometidos por uma mesma impressão, os dois tipos de homem a tomarão de modos muito distintos.

Por estar em estado de harmonia com sua própria natureza, a qual é racional, o sábio se caracteriza por ser aquele que melhor representa o mundo ao seu redor. Ao deparar-se com possíveis males, sejam estes ou não de âmbito futuro, o sábio não tenderá a exagerá-los; nem a desestabilizá-los no tempo; nem mesmo criará outros tantos males inexistentes. Nesta medida, mesmo que haja adversidades vindouras - o que é certo, haja vista que sempre as há de haver - o sábio não as interpretará tal qual o faz o temeroso, que as pressente, sente, e ressente, tornando sua vida desgraçada. Ora, uma vez que o temeroso é aquele que não consegue atribuir valores aos fenômenos mediante a medida da razão, quaisquer adversidades serão tomadas por ele como males. Dominado pelo temor, o temeroso criará maus juízos acerca de todas as coisas, tudo se lhe aparentando como mal, terrível, indizível e nefando. O temeroso representa, portanto, figura emblemática daquele que se encontra em conflito consigo mesmo e com o mundo que o circunda, julgando de modo desmedido e rejeitando a todo momento tudo o que pode lhe advir.

E é exatamente nesta medida que o temor e a coragem relacionamse à vida feliz: ora, como o próprio Sêneca explica, não é possível ser feliz temendo a tudo, antecipando males futuros e negligenciando o momento presente, o único capaz de nos oferecer a possibilidade da iniciativa moral - para retomar, mais uma vez, a interpretação de Goldschmidt. E é neste sentido que Sêneca costuma nos advertir que uma existência de desconfiança frente a tudo não pode ser tranquila e feliz (Ep. LXXIV, 5).

\footnotetext{
27 "De certas coisas, meu Lucílio, nenhuma virtude pode fugir; a natureza lembra-lhe a condição de sua mortalidade. E assim, não só contrairá alguém o rosto diante das coisas tristes, como tornará tremente diante do inesperado e enevoará se, estando num precipício, divisar-lhe abaixo a grande altura. Isso não é temor, mas uma afecção natural e inexpugnável à razão".
} 


\section{A figura do sábio}

Há, nestas considerações, dois aspectos que merecem maior atenção. Por um lado a capacidade do sábio de representar de modo saudável as coisas, interpretando tudo o que pode lhe advir como algo bom, pode sugerir que a ética estoica e de Sêneca seja intelectualista, uma vez que esta ação ética, de um modo geral, se baseia no equilíbrio do estado de alma do sábio - sempre em conformidade com sua natureza, parte do todo racional. ${ }^{28}$ Entretanto, por outro lado, há aí um outro aspecto importante a ser destacado: o homem cuja alma foi acometida por uma impressão externa tem de dar ou não o seu assentimento, ele tem de querer interpretar as coisas de uma dada maneira. ${ }^{29}$ Trata-se então, também, da vontade e do esforço.

Ora, numa medida, o que distingue essencialmente o estulto e o sábio com relação às adversidades vindouras é, sobretudo, o modo como as representam, isto já foi dito. $\mathrm{O}$ sábio, enquanto aquele que representa de modo saudável e avalia com medida, em inteira harmonia à sua natureza racional, constrói um estado de alma muito próximo do que

${ }^{28}$ Cf., a este respeito, as seguintes palavras de Sêneca, em Sobre a vida feliz: Ratio uera sensibus inritata et capiens inde principia - nec enim habet aliud unde conetur aut unde ad uerum impetum capiat - in se reuertatur. Nam mundus quoque cuncta complectens rectorque uniuersi deus in exteriora quidem tendit, sed tamen introsum undique in se redit. Idem nostra mens faciat (...). Hoc modo una efficietur uis ac potestas concors sibi et ratio illa certa nascetur, non dissidens nec haesitans in opinionibus comprensionibusque nec in persuasione, quae cum se disposuit et partibus suis consensit et, ut ita dicam, concinuit, summum bonum tetigit. - "Que a razão busque as excitações dos sentidos e, escolhendo-as como ponto de partida - eis que não tem outro ponto de onde alçar vôo e lançar-se rumo à verdade -, ela volte a si mesma. Pois o mundo abrange tudo, e Deus, que rege o universo, tende também a ficar do lado de fora, mas, no entanto, de toda a parte, Ele volta para dentro de si mesmo. Que nossa alma faça o mesmo (...). Desse modo, realizar-se-á a unidade de sua natureza e a união de suas faculdades e nascerá uma razão segura de si, sem discrepâncias nem hesitação em suas opiniões e suas concepções e nem em suas convicções, razão essa que, quando se põe em ordem, coordena-se em todas as suas partes e, digamos assim, harmoniza-se, ela atinge o sumo bem". (SÊNECA, Vit. VIII, 4-5 - trad. João Teodoro d'Olim Marote) ${ }^{29}$ Como contra-exemplo do sábio, temos Medeia, a qual dá o seu assentimento à paixão: Leuis est dolor, qui capere consilium potest/ et clepere sese: magna non latitant mala./ libet ire contra. - "Ligeira é a dor que consegue agir racionalmente e esconder-se em si. Os grandes males não ficam na sombra. Quero atacar!" (Medeia de Sêneca, v. 155157 - trad. Ana Alexandra Alves de Sousa, grifo nosso) 
Sêneca costuma tomar por tranquillitas animi ${ }^{30}$ Nesse sentido, sim, o traço que substancialmente os diferencia e os contrapõe é o modo como ambos lidam com a própria natureza racional; seja através do conflito, seja através da harmonia. E aqui vale lembrar a célebre máxima estoica: a felicidade consiste em viver segundo a natureza, ${ }^{31}$ a qual, em muitos aspectos, pode ser tomada como razão. Mas é importante ressaltar que o estado de harmonia é alcançado por um processo, no qual a instância da vontade assumirá papel de considerável importância. Não se adquire a capacidade de julgar de acordo com a razão sem um indizível esforço. Lembramos, a este respeito, as palavras do próprio Sêneca: Instemus itaque et perseueremus; plus quam profligauimus restat, sed magna pars est profectus uelle proficere. Huius rei conscius mihi sum: uolo et mente tota uolo. ${ }^{32}$

${ }^{30}$ SÊNECA, Ep.LXXV, 18: Expectant nos, $<$ si $>$ ex hac aliquando faece in illud euadimus sublime et excelsum, tranquillitas animi et expulsis erroribus absoluta libertas. Quaeris quae sit ista? Non homines timere, non deos; nec turpia uelle nec nimia; in se ipsum habere maximam potestatem: inaestimabile bonum est suum fieri. "Se um dia saírmos deste mundo de lama para as regiões sublimes e superiores teremos à nossa espera a tranquilidade da alma e, eliminadas todas as causas do erro, obteremos a liberdade absoluta. Queres saber em que consiste a liberdade? Em não temermos nem os homens nem os deuses; em não desejarmos nada que seja imoral ou excessivo; em termos o maior domínio sobre nós próprios: sermos donos de nós mesmos é um bem inestimável!" (trad. Segurado e Campos)

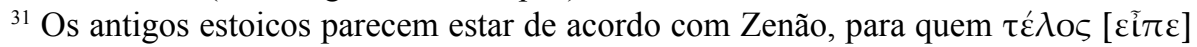

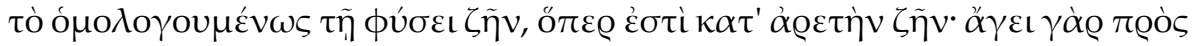
$\tau \alpha \dot{\tau} \tau \eta v \hat{\eta} \mu \tilde{\alpha} \varsigma \hat{\eta} \phi \dot{\sigma} \sigma \iota \varsigma^{-}$"il fine è vivere in modo coerente con la natura, ossia vivere secondo virtù: infatti la natura ci conduce alla virtù" Diog. Laërt. VII 87 [SVFI, 179]. De modo semelhante, Sêneca definirá: Nempe propositum nostrum est secundum naturam uiuere. - "Decerto, nosso propósito é viver conforme a natureza" (Ep. V, 4). A referida tradução do excerto de Diógenes Laércio do grego para o italiano é de autoria Roberto Radice, excerto este que faz parte da célebre compilação de fragmentos dos antigos estoicos estabelecida por Hans von Arnim.

${ }^{32}$ SÊNECA, Ep. LXXI, 36: "Desse modo, insistamos e perseveremos: resta mais do que já abatemos, mas grande parte do progresso é querer progredir. De uma coisa sou para mim consciente: quero e quero com toda a alma". 
E é com a tensão da alma, como bem o salientaram Voelke ${ }^{33} \mathrm{e}$ Bovis, ${ }^{34}$ que o homem - outrora preso de paixões - pode libertar-se do exagero e da loucura, para reivindicar-se a si mesmo. Reivindicandose a si mesmo, tomará sua relação com o mundo com outros olhos - o que antes eram males insuportáveis, tornam-se adversidades inerentes à vida humana. Autores como Motto (2001, p. 45-53) enfatizaram, inclusive, $o$ aspecto paradoxal do pensamento senequiano, para quem a adversidade parece ser, muitas vezes, preferível à boa fortuna, uma vez que é aquela que contribuirá para o fortalecimento da alma. Ora, ainda que sumariamente, caberia aqui uma menção aos indiferentes: se, por um lado, numa escala de valores que contemple categorias como o bem, o mal e os indiferentes, uma vida atribulada constituiria, sem dúvida, um dos indiferentes não preferíveis, vale lembrar que, se tomada numa dada perspectiva, as adversidades - ou, nas palavras de Sêneca, o combate contemplariam a melhor oportunidade para o exercício da reivindicação do homem de si mesmo, i.e., de seu exercício de aperfeiçoamento interior.

E é nesta direção que trilhamos até aqui, uma vez que nossa argumentação se constrói, num âmbito mais geral, através da tentativa da explicitação da relação entre a disposição de alma e a proximidade ou distância da vida feliz - e aqui, vale dizer, entre a força de alma ou coragem e a vida feliz -, segundo a perspectiva senequiana. Ora, se de fato, como nosso autor argumenta, o temeroso se caracteriza por ser aquele que torna a própria vida desgraçada, sobretudo pelo modo como toma o mundo que o cerca; o corajoso e forte, ao contrário, "não interpreta tudo da pior maneira", ${ }^{35}$ mas vê a tudo com bons olhos, revelando uma impressionante harmonia entre o seu estado interior e o mundo que o cerca. Nesta medida, adversidades nada mais são que eventos inerentes à vida humana, os quais contribuem para o nosso fortalecimento.

Que o ideal ético estoico esteja contemplado na figura do sábio que representa um homem que atualizou plenamente as potencialidades

\footnotetext{
${ }^{33}$ VOELKE, 1973, p. 169-170: "Fixer un but à son vouloir ne suffit pas, il faut encore persévérer (...). Dans cette conception, la volonté se manifeste comme une force". ${ }^{34}$ BOVIS, 1948, p. 76-80. Bovis enfatiza a impossibilidade de reduzir a moralidade à razão: ora, se o processo de aperfeiçoamento fosse só uma questão de compreensão, por que razão o homem teria tanta necessidade de exercitar-se? A referida questão tange, também, a esfera da vontade, portanto.

${ }^{35}$ SÊNECA, Ep. LXXXI, 25: Non uertit omnia in peius.
} 
de seres humanos adultos racionais, não há dúvida. De fato, o sábio será, por excelência, o racional. Que a instância da vontade ganhe corpo e relevância em meio a este processo, também nos parece claro - embora valha salientar que esta temática merece novas investigações, tal qual o excelente trabalho empreendido por Inwood. ${ }^{36}$ Contudo, não devemos nos esquecer - vale aqui lembrar mais uma vez - de que a problemática das paixões, e não só na tradição estoica, mas, ainda, em Sêneca, é muito mais rica e complexa do que parece e que o sábio, certamente, não seria um homem apático, tal qual o entendemos hoje ao utilizarmos o adjetivo 'estoico'. Ora, se por um lado Sêneca parece não ter discorrido suficientemente acerca da doutrina das eupatheíai, por outro, torna-se nítido que, em sua obra, o conceito de vida feliz incluiria, certamente, a serenidade, a alegria e as verdadeiras amizades. ${ }^{37}$ Acerca desta problemática, retomamos o esclarecimento prestado por nosso autor no primeiro passo da epístola CXVI:

Nam cum tibi cupere interdixero, uelle permittam, ut eadem illa intrepidus facias, ut certiore consilio, ut uoluptates ipsas magis sentias: quidni ad te magis peruenturae sint si illis imperabis quam si seruies? (Ep.CXVI, 1$)^{38}$

Nesse sentido, vale lembrar que, embora a referida problemática atinja proporções que ultrapassam os limites de nossos modestos objetivos para o presente estudo, fica claro que, mesmo manifestando-se contrário às paixões e preocupado com o perigo de as mesmas, se configuradas

\footnotetext{
${ }^{36}$ Referimo-nos aqui ao artigo "The will in Seneca The Younger", o qual pode ser encontrado apud INWOOD, 2005, p. 132-156.

${ }^{37}$ Se Sêneca e os estoicos, de um modo geral, rejeitam a metriopátheia dos peripatéticos, não se pode daí deduzir que eles prescrevam uma vida inteiramente sem emoções. A este respeito, lembramos a excelente observação de Lévy: "Entre le plaisir et l'amitié tels que le vit le stultus e tels qu'ils sont vécus par le sage, il n'y a pas véritablement rupture, car le stoïcisme répugne à la rupture, mais une mutation qualitative profonde. La sagesse ne change pas nécessairement les formes que prennent ces expériences humaines, mais la manière, l'ésprit dans lesquels elles sont vécues". (LÉVY, 2012/2013, p. 123 - grifo nosso)

38 "Na verdade, quando a ti proibir o desejar, permitirei o querer, a fim de que faças as mesmas coisas sem temor, a fim de que com mais propriedade deliberes, a fim de que sintas melhor os próprios prazeres: por que tais coisas não te chegariam mais facilmente, se a elas dominares, do que se lhes servires de escravo?"
} 
em vício, tiranizarem a alma, Sêneca não parece pretender descartar da vida espiritual as boas emoções. ${ }^{39}$

\section{Considerações finais}

Assim, é chegado o momento de retomar algumas considerações, a fim de pôr termo ao presente estudo. A este respeito, vale lembrar que nosso propósito fundamental aqui era o de explicitar, a partir da descrição empreendida por Sêneca na epístola XIII, o perfil psicológico do homem temeroso. Partindo da referida descrição, buscamos delimitar o conceito de temor, com o que nos deparamos com a definição de uma paixão, enquanto impulso exagerado, direcionada à antecipação de males futuros. Detalhada esta paixão, passando por seus aspectos, faltava-nos explicitar, enquanto oposta à figura do estulto, aquela relativa ao sábio, a fim de postular, então, o critério que os diferenciava no modo de agir e que os configurava como próximos ou não da vida feliz. Neste sentido, o sábio nos apareceu como aquele que, por estar em arranjo com sua própria natureza, a qual é racional, vive em estado de tranquilidade, nutrido de força e coragem diante de adversidades inerentes à condição humana. Sem definir o critério de distinção da postura do sábio e do estulto apenas como o da racionalidade, em sentido estrito, retomamos a importância da instância da vontade no processo de aperfeiçoamento - tentando nos distanciar, assim, de uma interpretação meramente intelectualista da ética estoica de Sêneca. Procuramos ainda, nesta direção, defender também a tese de que o sábio estoico, embora excelente no cumprimento de sua função racional, não seria, absolutamente, um homem de caráter apático e frio, distante das experiências humanas, podendo, assim, mostrar-se ainda repleto de boas emoções. Em todo caso, e atendo-nos ao nosso principal objetivo aqui, esperamos ter tido sucesso em explicitar, então, que o homem temeroso é aquele que, por conta de seu estado de perturbação interno, mais distante se encontra da vida feliz - esta entendida enquanto uma vida transcorrida com tranquilidade da alma, oriunda do fortalecimento do eu e da concentração no momento presente.

\footnotetext{
${ }^{39}$ A alegria, oriunda do alcance da virtude, é de âmbito interior ao homem e, por isso, perene - ao contrário do mero contentamento, proveniente de fatores externos. (SÊNECA, Ep. LIX, 14-18)
} 


\section{Referências}

ARNIM, H. Stoici antichi, tutti i frammenti. Trad. Roberto Radice. Milano: Bompiani, 2002.

BOVIS, A. La sagesse de Sénèque. Paris: Aubier, 1948.

FITCH, J. (org.). Oxford readings in classical studies: Seneca. Oxford/ New York: Oxford University Press, 2008.

GOLDSCHMIDT, V. Le système stoïcien et l'idée de temps. Paris: J. Vrin, 1953.

GRIMAL, P. Sénèque ou la conscience de l'empire. Paris: Les Belles Lettres, 1979.

HADOT, P. La citadelle intérieure: introduction aux Pensées de Marc Aurèle. Paris: Fayard, 1992.

HADOT, P. O que é a filosofia antiga? Trad. Dion Davi Macedo. São Paulo: Loyola, 1999.

INWOOD, B. (org.). Os estoicos. Trad. Raul Fiker. São Paulo: Odysseus, 2006.

INWOOD, B. Reading Seneca: stoic philosophy at Rome. New York: Oxford University Press, 2005.

LÉVY, C. Plaisir et amitié dans les Lettres à Lucilius. Ítaca: Quaderns Catalans de Cultura Clàssica, Barcelona, n. 28-29, p. 119-131, 2012/2013. LONG, A.; SEDLEY, D. Les philosophes hellénistiques: vol. 2 les stoïciens. Trad. Jacques Brunschwig et Pierre Pellegrin. Paris: Flammarion, 2001.

MARCO AURÉLIO. Meditações. Trad. Jaime Bruna. São Paulo: Cultrix, 1964.

MOTTO, L. Further essays on Seneca. Frankfurt/New York: Peter Lang, 2001.

REYDAMS-SCHILS, G.The Roman Stoics: self, responsibility and affection. Chicago: University of Chicago Press, 2005.

SENECA. Ad Lucilium epistulae morales. With an English translation by Richard Gummere. Cambridge, Mass./London: Harvard University Press, 1989 (3 vols.). 
SÉNECA. Cartas a Lucílio. Trad. J. A. Segurado e Campos. Lisboa: Fundação Calouste Gulbenkian, 2009.

SÉNECA. Medeia. Trad. Ana Alexandra Alves de Sousa. São Paulo: Annablume Clássica, 2012.

SENECA. Moral Essays. With an English translation by John W. Basore. London: Heinemann, 1932/1935 (3 vols., vol. II-III).

SENECA. Sobre a vida feliz. Trad. João Teodoro d'Olim Marote. São Paulo: Nova Alexandria, 2005.

SÉNĖQUE. Lettres a Lucilius. Trad. Henri Noblot. Paris: Les Belles Lettres, 1947/1969.

USENER, H. Epicurea. Cambridge: Cambridge University Press, 2010. VOELKE, A.-J. L'idée de volonté dans le stö̈cisme. Paris: Presses Universitaires de France, 1973. 